Bożena Gierat-Bieroń

Uniwersytet Jagielloński

DOI: $10.19195 / 2450-274 X .3 .5$

\title{
Konceptualizacja idei ochrony dziedzictwa europejskiego Wspólnoty Europejskiej jako fundament ustaleń art. 128 traktatu z Maastricht
}

\begin{abstract}
Abstrakt: Celem niniejszego artykułu jest próba wyjaśnienia genezy oraz roli dziedzictwa europejskiego w kształtowaniu nowej świadomości kulturowej Europejczyków. Dziedzictwo, rozumiane u podstaw procesu włączania go do polityki wspólnotowej w kategoriach ochrony architektonicznych i archeologicznych zabytków starożytnych, stawało się w trakcie procesów decyzyjnych lat 70. i 80. XX w. pojęciem szerszym, asymilującym dobra materialne i niematerialne, takie jak pamięć, pamięć zbiorowa i tożsamość. Okres poprzedzający ustanowienie traktatu z Maastricht (1993 r.) był czasem konceptualizowania i powolnego europeizowania pojęcia „dziedzictwo”. Na poziomie zarówno definicyjnym, jak i funkcji pełnionej względem innych obszarów życia przekształcało się ono w dziedzinę, która może podlegać ponadnarodowemu interwencjonizmowi czynionemu w imię dobra zbiorowego oraz niepodważalnych wartości europejskich. To w żadnym stopniu nie koliduje z jego narodowym znaczeniem oraz zachowaniem zasady suwerenności państw, przestrzeganej w UE. ropejskie

Słowa kluczowe: dziedzictwo kulturowe, zabytki, pamięć zbiorowa, tożsamość, polityki eu-

\section{Conceptualisation of the idea of the protection of European heritage} of the EC as a foundation of the provisions of art. 128 of the Maastricht Treaty

Abstract: The paper attempts to explain both roots and a role of European heritage in shaping cultural awareness in European Union. At its beginning, the heritage was considered solely as a protection of historic sites and architecture. During 70s and 80s, when decisions shaping European Union were voted and made, the term was considerably broadened to include apart from material also non material culture. The ideas of memory, collective memory, or identity became a part of cultural heritage at that time. During a period prior to Maastricht Treaty of 1993, the concept of heritage underwent the process of further conceptualization and Europeanization. The heritage started to
\end{abstract}


be perceived as a domain which can be subject, in the name of common good and protection of indisputable and fundamental European values, to over national interventionism. This, however, cannot collide or stay in conflict with national policies protecting local heritage. The latter is compatible with the idea of state members sovereignty and it is fully respected within the EU.

Keywords: cultural heritage, monuments, collective memory, identity, European policies

\section{Problematyka ochrony dziedzictwa europejskiego znajdowała się przez wiele} lat w kompetencjach dwóch międzynarodowych organizacji: $\mathrm{UNESCO}^{1}$ oraz Rady Europy ${ }^{2}$. Ochrona dziedzictwa narodowego poszczególnych krajów europejskich, zgodnie z zasadą suwerenności państw, leżała zawsze w zakresie obowiązków rządów oraz samorządów terytorialnych ${ }^{3}$. Niniejszy artykuł ma na celu wyjaśnienie

1 UNESCO jako wyspecjalizowana organizacja ONZ została założona w 1945 r. w Londynie. Jej zadaniem statutowym było wspieranie współpracy międzynarodowej m.in. na polu kultury i nauki. W 1977 r. UNESCO ogłosiło pierwszą wersję listy światowego dziedzictwa, czyli spis instytucji i pamiątek kultury, które ze względu na unikatową i uniwersalną wartość należy chronić. W $2014 \mathrm{r}$. lista światowego dziedzictwa UNESCO obejmowała 1031 obiektów. Dwie konwencje UNESCO miały znaczący wpływ na pierwsze decyzje państw Wspólnoty Europejskiej w zakresie ochrony dziedzictwa europejskiego: Konwencja UNESCO o ochronie dóbr kulturalnych w razie konfliktu zbrojnego z 14 maja 1954 r. (Haga) oraz Konwencja UNESCO w sprawie ochrony światowego dziedzictwa kulturalnego i przyrodniczego z 16 listopada 1972 r. (Paryż). Konwencja haska była odpowiedzią na niedawne doświadczenia wojenne w Europie, które doprowadziły do ogromnych strat dóbr kultur narodowych. Miała przeciwdziałać takiej sytuacji w przyszłości, dlatego jako najważniejsze przesłanie wprowadzała pojęcie ochrony specjalnej dla dóbr kultury (wraz z utworzeniem znaku rozpoznawalnego do obiektu chronionego specjalnie), którym miały zostać opatrzone odpowiednie obiekty i zabytki. Zabytki te miały, zgodnie z konwencją, być kategorycznie wyjęte spod operacji wojennych. Wprowadzono zakaz okupacji tychże obiektów, a także zakaz kradzieży i rabunku (art. 4, pkt 3, www. unesco.pl/fileadmin/user_upload/pdf/Haga.pdf, dostęp: 6 grudnia 2015). Konwencja paryska ustanawiała natomiast system współpracy i pomocy międzynarodowej na rzecz ochrony zabytków. Powoływała do życia Komitet Dziedzictwa Światowego, który w przyszłości układał „Listę Światowego Dziedzictwa", czyli wykaz unikatowych dóbr kultury. Typowania do listy miały pochodzić ze strony suwerennych państw. Ustanowiono też Fundusz Ochrony Światowego Dziedzictwa, który miał być tworzony ze składek członkowskich, darowizn i sponsoringu oraz procentów od kapitału. Więcej na ten temat zob. http://www.unesco.pl/fileadmin/user_upload/pdf/Konwencja_o_ochronie_swiatowego_dziedzictwa.pdf (dostęp: 5 grudnia 2015).

2 Rada Europy rozpoczęła politykę w zakresie dziedzictwa od Europejskiej Konwencji Kulturalnej, którą podpisano 19 grudnia 1954 r. w Paryżu. Strony zgodziły się, że chronione elementy kultur narodowych stanowią wspólne dziedzictwo europejskie. Ponadto uznano, iż oprócz wymiany bilateralnej zostaną zainicjowane wspólne działania na rzecz rozwoju kultury europejskiej w wymiarze uczenia języków, historii i cywilizacji narodów oraz cywilizacji europejskiej. Współpracą miał kierować Komitet Ekspertów Kulturalnych Rady Europy. Przełomowym dokumentem w zakresie ochrony dziedzictwa była Europejska Karta dziedzictwa architektonicznego, ustanowiona 26 września 1975 r. w Amsterdamie. Według jej zapisów państwa członkowskie Rady Europy miały promować ochronę dziedzictwa architektonicznego, opierając się na pryncypiach zintegrowanej konserwacji wypracowanej przez Kartę wenecką z $1964 \mathrm{r}$.

3 Finansowanie zabytków narodowych, regionalnych czy lokalnych leży w obowiązkach poszczególnych krajów UE. Służą temu odpowiednie ustawy krajowe, rozporządzenia i przepisy. Pieniądze na ochronę zabytków asygnują rządy, tworząc różnego typu mechanizmy wsparcia: fundusze, agencje, komitety itp. Nie istnieją żadne zintegrowane akty prawne unijne w zakresie ochrony dzie- 
przyczyn oraz przesłanek, dla których Wspólnota Europejska, mimo iż istniały organizacje specjalizujące się $w$ kwestiach opieki nad dziedzictwem, zainteresowała się w latach 70. XX w. tematyką ochrony obiektów kultury. Praca ta ma również za zadane interpretację najważniejszych definicji pojęcia „dziedzictwo europejskie”, formułowanych w dokumentach wspólnotowych, a także wyjaśnienie zasadności priorytetów ustalonej na początku lat 90. XX w. polityki kulturalnej UE w zakresie dziedzictwa.

Jeden z pierwszych dokumentów Wspólnoty Europejskiej dotyczących dziedzictwa odnosił się do zabezpieczania zabytków przed degradacją. Tak sformułowano rekomendację Komisji 75/65/WE z 20 grudnia 1974 r. w sprawie ochrony dziedzictwa architektonicznego i naturalnego ${ }^{4}$. Biorąc pod uwagę fakt, że od połowy lat 60. specjaliści od ochrony zabytków wypracowywali standardy konserwacji i rewaloryzacji, a także dyskutowali o idei zabytku ${ }^{5}, \mathrm{w}$ tym zabytku architektonicznego, rozszerzająca się od lat 70 . Wspólnota niejako przyłączyła się do ogólnoeuropejskiej dyskusji. Rekomendacja mówiła zatem o zaniepokojeniu Komisji złą kondycją architektury europejskiej oraz obszarami poprzemysłowymi. Powoływano się na przyjętą w listopadzie 1972 r. Konwencję UNESCO o ochronie światowego dziedzictwa kultury i dziedzictwa naturalnego, która obligowała kraje stowarzyszone do wzmocnienia działań w tym zakresie. Poparła też pomysł obchodów „Roku Europejskiego Dziedzictwa Kulturowego” (1975 r.) proponowany przez Radę Europy. Wskazała na możliwość realizacji dwóch zadań ze strony państw Wspólnoty: 1) inicjowania projektów pilotażowych związanych z renowacją zaniedbanych budynków i miejsc oraz 2) inicjowania działań mających na celu pobudzanie świadomości społecznej odnoszącej się do wpływu dziedzictwa europejskiego na konkretne otoczenie, pozostające pod zarządem administracji publicznej różnych szczebli. Dokument Wspólnoty Europejskiej z 1977 r. — Community Action in the Cultural Sector ${ }^{6}$, odnoszący się do całości problematyki kulturalnej - w zakresie dziedzictwa prognozował współfinansowanie stypendiów naukowych (w latach 1976-1978) na pobyty w trzech ośrodkach badawczych spe-

dzictwa europejskiego. Po traktacie z Maastricht powstały natomiast odpowiednie programy wspomagające ten sektor.

4 Commission Recommendation of 20 December 1974 to Member States concerning the protection of the architectural and natural heritage, OJ L21, 28 January 1975, s. 22, http://www. ur-lex. europa.eu/legal-content/EN/TXT/?uri=CELEX:31975H0065 (dostęp: 15 grudnia 2014).

${ }^{5}$ Karta wenecka (Międzynarodowa karta konserwacji i restauracji zabytków i miejsc zabytkowych) z 1964 r. wprowadziła zasadę rewaloryzacji oryginalnej substancji zabytku oraz materiału, z którego został on zrobiony, a także wprowadziła warunki, na których może następować współczesna dobudowa do obiektu chronionego, i określiła, w jaki sposób powinno się dbać o najbliższe otoczenia budynku o wartości historycznej. Podczas spotkania w Wenecji zainicjowano działalność Międzynarodowej Rady Ochrony Zabytków i Miejsc Historycznych (ICOMOS - International Council on Monuments and Sites).

${ }^{6}$ Community Action in the Cultural Sector. Commission Communication to the Council sent on 22 of November 1977, „Bulletin of the European Communities”, Supplement 6/77, COM (77) 560, 2 December 1977. 
cjalizujących się w omawianej tematyce. W ten sposób WE wybierała ścieżkę edukacyjną dla problematyki dziedzictwa.

Początek lat 80. XX w. przyniósł większy impuls do zmian. Dyskusje parlamentów krajowych oraz Parlamentu Europejskiego dotyczyły wówczas katastrofalnego stanu zabytków basenu Morza Śródziemnego. Poważną debatę na ten temat rozpoczęły kraje południowe wstępujące w tym czasie do Wspólnoty (Grecja, Hiszpania, Portugalia). Wszystkie otrząsały się z traumatycznych doświadczeń wieloletnich reżimów politycznych i zapóźnienia cywilizacyjnego. Ważnym partnerem inicjowanych działań stawała się oczywiście Rada Europy, wraz z jej najnowszą Konwencją o ochronie dziedzictwa architektonicznego Europy z 1985 r. ${ }^{7}$ Eliot Tretter ${ }^{8}$ uważa, że troskę Parlamentu Europejskiego o starożytne zabytki Europy wymusili parlamentarzyści włoscy i francuscy. Świadomi faktu, że państwa Wspólnoty zamierzają wprowadzać pewne rozwiązania w sektorze kultury, apelowali o konieczność rozszerzenia działań na ochronę dziedzictwa i rozwój turystyki. Według danych UNESCO z tamtego okresu $60 \%$ wszystkich zabytków europejskich oraz 50\% zabytków archeologicznych znajdowało się na terenie Włoch, a ich stan techniczny był zły. Włoscy i francuscy politycy jeszcze w połowie lat 70. apelowali o pilne utworzenie fundacji europejskiej, która gromadziłaby fundusze na renowację najstarszych pamiątek kultury. Dekadę później wystosowywano interpelacje poselskie z prośbą o dofinansowanie krajowych procesów rewaloryzacyjnych, zwłaszcza na obszarach basenu Morza Śródziemnego. Włoski komunista, Guido Fanti, wieloletni członek parlamentarnej Komisji ds. Młodzieży, Kultury, Edukacji, Informacji i Sportu, w jednej z rezolucji z 1983 r. postulował wręcz przeznaczenie 1\% budżetu Parlamentu Europejskiego na działania w zakresie kultury.

Tretter podkreśla wyjątkową aktywność włoskich socjalistów i komunistów w tym okresie, wymieniając: Giovanniego Papapietro, Gaetamo Arfé, Marie Pedini, Giuseppe Amadeiego ${ }^{9}$ oraz Carlo Ripa de Meana jako najważniejszych polityków

7 Konwencja o ochronie dziedzictwa architektonicznego Europy została uchwalona w Granadzie w 1985 r. We wstępie mówiła, że „dziedzictwo architektoniczne stanowi niczym niezastąpione odzwierciedlenie bogactwa i zróżnicowania dziedzictwa kulturowego Europy, jest bezcennym świadectwem naszej przeszłości i stanowi wspólne dziedzictwo wszystkich Europejczyków", co miało podkreślić znaczenie pamiątek architektury europejskiej jako widocznego i realnego symbolu wspólnych doświadczeń historycznych. Konwencja definiowała pojęcie dziedzictwa architektonicznego, dzieląc budowle na pojedyncze obiekty zabytkowe, zespoły budynków o charakterze historycznym oraz tereny stanowiące zwartą jednostkę urbanistyczną podlegającą ochronie. Dokument zobowiązywał wszystkie strony do wdrożenia systemu ochrony prawnej dziedzictwa architektonicznego oraz polityki konserwacji zabytków. Artykuł 17 konwencji mówił nawet o Europejskiej Koordynacji Polityki Konserwacji Zabytków, która polegała na możliwości wymiany informacji zwłaszcza z zakresu stosowania nowych technologii oraz identyfikowania i inwentaryzowania zabytków architektonicznych. Więcej na ten temat zob. ww.nid.pl/upload/iblock/621/6219bf31b7025833330c1c4182cd5215. pdf (dostęp: 15 grudnia 2015).

8 E. Tretter, The 'value' of Europe: The political economy of culture in the European community, „Geopolitcs” 2011, nr 16, s. 926-948, www.tandfonline.com/loi/fgeo20 (dostęp: 20 lutego 2015).

9 Giuseppe Amadei był również autorem dziś już niedostępnego raportu pod nazwą Community Action in the Cultural Sphere as a Whole. 
torujących drogę polityce kulturalnej lat 1980-1985 w zakresie dziedzictwa, głównie ze względu na ich możliwości decyzyjne wynikające z funkcji członkostwa w parlamentarnej Komisji ds. Młodzieży, Kultury, Edukacji, Informacji i Sportu. Wielu polityków naciskało na wsparcie ochrony zabytków z funduszy strukturalnych (Europejskiego Funduszu Rozwoju Regionalnego i Europejskiego Funduszu Spójności) oraz nowego mechanizmu finansowego, jakim miały się stać Zintegrowane Programy Śródziemnomorskie (ZPŚ). Zostały one uruchomione na podstawie decyzji Rady Europejskiej (29-30 czerwca 1985 r.) w związku z akcesją Hiszpanii i Portugalii do Wspólnoty. ZPŚ miały gromadzić środki z funkcjonujących funduszy strukturalnych i przekazywać je na dofinansowanie prac restrukturyzacyjnych zapóźnionego południa. Kolejnym przywoływanym źródłem wsparcia był proponowany przez Komisję Europejską oraz Radę ministrów kultury Fundusz Europejskich Zabytków i Miejsc Historycznych (European Historical Monuments and Sites Fund). Politycy i ministrowie kultury zobowiązywali się do podjęcia lobbingu na rzecz uzyskania pożyczek z Europejskiego Banku Inwestycyjnego, które zasiliłyby tworzony Fundusz. Seria zapytań parlamentarnych na temat powołania Funduszu Europejskich Budynków i Miejsc Historycznych miała miejsce w pierwszym półroczu 1984 r. ${ }^{10}$

Oprócz tworzenia i wykorzystywania funduszy przewidywano inne formy finansowania dziedzictwa. Z zasobów programu Eureka planowano dofinansowanie badań naukowych w zakresie konserwacji, a także praktycznych zajęć w postaci warsztatów dla administratorów i menedżerów obiektów zabytkowych. Zalecano większą profesjonalizację zawodową w tym obszarze. Europejski Fundusz Spójności radzono wykorzystać w celu tworzenia stypendiów konserwatorskich. W ramach popularyzowanej od 1986 r. idei People’s Europe proponowano nagłaśnianie wolontariatu w sektorze ochrony zabytków, który mógłby skutkować udziałem dzieci ze szkół artystycznych w obozach/warsztatach konserwatorskich.

Wszystko to jednak pozostawało w planach. Instytucjami, które realnie rozpoczęły proces finansowego wsparcia dla dziedzictwa w latach 80., były Komisja Europejska oraz Parlament Europejski. Udzielano doraźnej pomocy finansowej projektom renowacyjnym zgłaszanym przez poszczególnych posłów, a tym samym ich kraje. W ten sposób w pierwszej połowie lat 80. sfinansowano kilka pojedynczych prac, np. odnowę włoskich domów stylu Dalekiego Wschodu miasteczka Trullo, w regionie Apulia ${ }^{11}$; renowację średniowiecznej fortyfikacji bastionowej toskańskiego miasta Lukka ${ }^{12}$; kompleksowe renowacje włoskiej Campanii i Basilicaty ${ }^{13}$. Pracami konserwatorskimi objęto też wiktoriańskie mola ${ }^{14}$ rozciągające się wzdłuż wybrzeży Wielkiej Brytanii; pozostałości epoki brązu w Holandii ${ }^{15}$ oraz

10 O. Colligaro, From 'European cultural heritage' to 'cultural diversity', „Politigue Européenne” 3, 2014 , nr 45, s. 60-85.

11 DOC $1-566 / 80$.

12 DOC 1-504/81.

13 DOC $1-52 / 81$.

14 DOC $1-876 / 80$.

15 DOC 1-370/82. 
wykopaliska archeologiczne. W Grecji rozpoczęły się prace restauracyjne Akropo$\mathrm{lu}^{16}$, wspierane $\mathrm{z}$ budżetu Wspólnot, a także renowacja Eleusis ${ }^{17}$, ośrodka kultu Demeter i Persefony. Pojawiały się kolejne akty prawne regulujące dalsze działania w zakresie dziedzictwa. Należały do nich: Rezolucja Parlamentu Europejskiego z 14 października 1982 r., Rezolucja Ministrów Kultury z 13 listopada 1986 r. oraz Postanowienie Komisji Europejskiej z 28 listopada 1988 r. Przyjrzyjmy się bliżej tym dokumentom.

We wstępie Rezolucja Parlamentu Europejskiego (1982 r. $)^{18}$ orzekała o fatalnym stanie zabytków europejskich, który wynikał z wysokiego wskaźnika zanieczyszczenia powietrza oraz zaniedbań finansowych. Zabytki architektoniczne uznano za permanentnie niedoinwestowane. Rezolucja podnosiła do rangi obowiązku publicznego ochronę zabytków o charakterze regionalnym, w imię formułowanej tu idei o „wzrastaniu świadomości wartości archeologicznego i architektonicznego dziedzictwa dla naszej europejskiej kultury i historii, a także świadomość naszej europejskiej tożsamości"19. Politykę konserwatorską należało potraktować jako konieczność chwili. Należało zinwentaryzować zabytki znajdujące się w najgorszym stanie techniczno-budowlanym i rozpocząć prace renowacyjne. Miały one przynieść efekty nie tylko w postaci odnowy samego obiektu, lecz także - jak przewidywała Karta wenecka - zmian infrastrukturalnych najbliższego otoczenia.

Zauważalna jest zbieżność postulatów Rezolucji PE z postanowieniami Rady Europy. W obu przypadkach szeroko zakrojone prace konserwatorskie budowli architektonicznych zaczynały być postrzegane jako czynnik mobilizujący zmiany urbanistyczne oraz wspomagające ruch turystyczny. Rezolucja wzywała również do stworzenia zabezpieczenia finansowego zabytków ze źródeł publicznych i prywatnych. Powtórzyła także postulat stworzenia Europejskiego Funduszu Zabytków i Miejsc Historycznych (European Historic Monuments and Sites Fund). Ponadto odnowa zabytków miała być dofinansowana z Europejskiego Funduszu Społecznego oraz Funduszu Rolnictwa i Gwarancji Rolnych. Za model współpracy ponadnarodowej w tym zakresie przyjęto powołanie władzy wyższej (ang. supreme authority) jako ciała koordynującego europejską konserwację zabytków i ochronę dziedzictwa architektonicznego. Ciało to gromadziłoby informacje o miejscach wymagających natychmiastowego zabezpieczenia, w tym zabezpieczenia przed zanieczyszczeniami. Zalecano stałą współpracę rządów krajowych i władz regionalnych poszczególnych krajów członkowskich $\mathrm{z}$ takim ciałem $\mathrm{w}$ celu sporządzania statystyk i możliwości szybkiej reakcji. Po raz kolejny wyrażano też chęć pomocy dla ośrodków kształcenia konserwatorów i technik konserwatorskich (Grenoble,

16 DOC $1-557 / 81$.

17 DOC 1-363/81.

18 European Parliament resolution on the protection of the architectural and archaeological heritage, OJ C 267/25, 11 October 1982.

19 „[A]ware of the importance of the architectural and archaeological heritage for our European culture and history and awareness of our European identity" - ibidem, s. 25. 
Leuven, Wenecja, Rzym). Ponadto ustalono, że Komisja Europejska wraz z ekspertami Rady Europy co roku będzie wybierać zabytki wymagające natychmiastowego wsparcia ze strony Wspólnoty. Rozważano kwestię redukcji podatku VAT w wypadku konserwacji zabytków prowadzonych przez indywidualnych właścicieli. Rezolucja PE podkreślała związek kultury z rozwojem innych obszarów życia publicznego i innych dziedzin. Dostrzegała wagę ochrony dziedzictwa architektonicznego dla wsparcia ruchu turystycznego na terenach miejskich i wiejskich.

Niestety wiele postulatów ciągle pozostawało na papierze. To jak faktycznie, a nie postulatywnie przebiegała pomoc Wspólnoty udzielona zabytkom europejskim w latach 80., co poniekąd wynikało z postanowień omówionej Rezolucji, najlepiej ilustruje dokument Komisji Europejskiej o nazwie New Prospect for Community Cultural Action przygotowany przez polityka włoskiej lewicy Roberto Barzantiego. Wydany w 1992 r. dokument sumował siedem lat pomocy finansowej dla dziedzictwa i pozwalał na pierwsze wnioski. Przytoczmy retrospektywnie kilka faktów z tego raportu. Barzanti wymienia w nim obszary wsparcia dziedzictwa architektonicznego w latach 80 . i na przełomie lat 80. i 90. :

1. specyficzne projekty konserwatorskie finansowane przez państwa Wspólnoty;

2. dofinansowanie prac konserwatorskich prowadzonych w europejskich obiektach o szczególnej wartości historycznej;

3. granty na warsztaty technik konserwatorskich;

4. sponsorowanie wydarzeń typu wykłady, wystawy, konferencje z zakresu renowacji zabytków.

W pierwszym (1) obszarze raport podaje konkretne zestawienia liczbowe. Były to granty przyznawane przez Komisję w toku procesu aplikacyjnego obejmującego ocenę projektów przez krajowych ekspertów oraz panel ekspertów międzynarodowych. Informacje o konkursie aplikujący uzyskiwali z corocznych ogłoszeń Dziennika Urzędowego Wspólnoty Europejskiej. Tabela 1 ilustruje proces przekazywania dotacji. Dotacja WE wynosiła nie więcej niż jedną trzecią wkładu do całości budżetu danego projektu.

Tabela 1. Proces przekazywania dotacji Wspólnoty Europejskiej w latach 1984-1991

\begin{tabular}{|c|r|r|r|r|r|r|r|r|r|}
\hline Czas trwania dotacji & 1984 & 1985 & 1986 & 1987 & 1988 & 1989 & 1990 & 1991 & Razem \\
\hline Roczny budżet (tys. ECU) & 400 & 500 & 700 & 2100 & 2700 & 2400 & 2600 & 2600 & 14000 \\
\hline Liczba zgłoszeń & 113 & 144 & 135 & 129 & 441 & 822 & 1159 & 433 & 3376 \\
\hline $\begin{array}{c}\text { Liczba projektów } \\
\text { wybranych }\end{array}$ & 12 & 12 & 13 & 22 & 30 & 24 & 26 & 37 & 176 \\
\hline $\begin{array}{c}\text { Średnia wysokość grantu } \\
\text { na projekt (w tys. ECU) }\end{array}$ & 33 & 42 & 54 & 95 & 90 & 100 & 100 & 70 & - \\
\hline
\end{tabular}

Źródło: opracowanie własne na podstawie: Communication from the Commission to the Council, the European Parliament and the Economic and Social Committee, New Prospect for Community Cultural Action, COM (92) 149 Final, Brussels 29 April 1992. 
Wykres 1 ilustracje dane zebrane w tabeli 1. Stanowi zestaw kwot wsparcia Komisji Europejskiej dla dziedzictwa w układzie rocznym. Widać na nim, że większe dotacje na specyficzne projekty konserwatorskie finansowane przez państwa Wspólnoty występowały od 1987 r. i utrzymywały się do 1991 r. - na wysokości powyżej 2000 tys. ECU, co oczywiście było dotacją niską jak na potrzeby tak kosztownego sektora. Należy zwrócić uwagę, że na przełomie lat 1986-1987 budżet zwiększono (skokowo) prawie trzykrotnie.

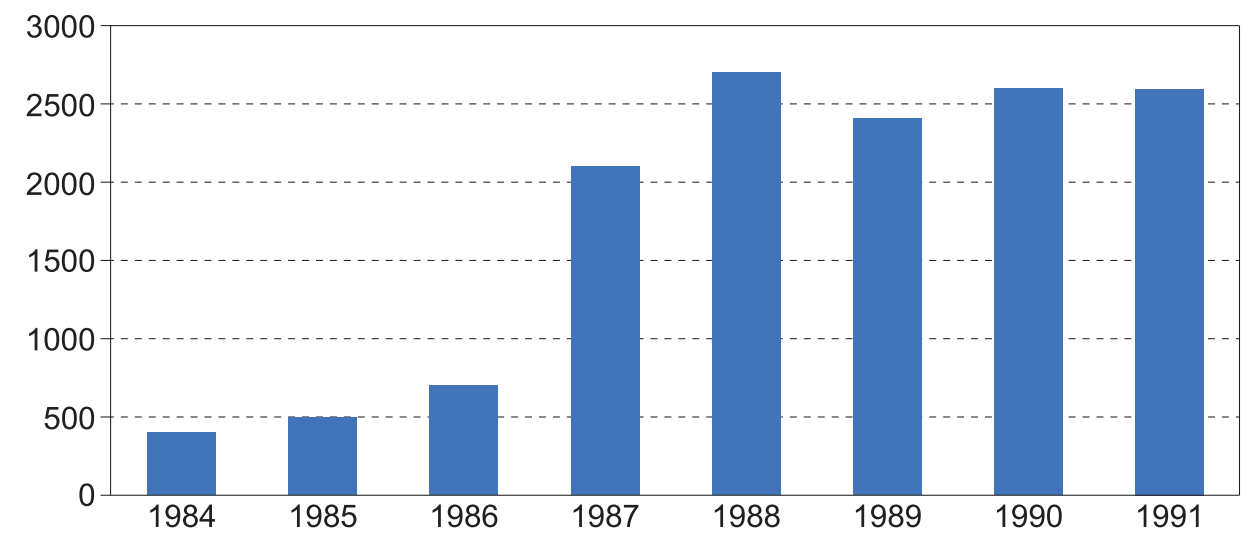

Wykres 1. Roczny budżet (w tys. ECU)

Źródło: opracowanie własne na podstawie: Communication from the Commission to the Council, the European Parliament and the Economic and Social Committee, New Prospect for Community Cultural Action, COM (92) 149 Final, Brussels 29 April 1992.

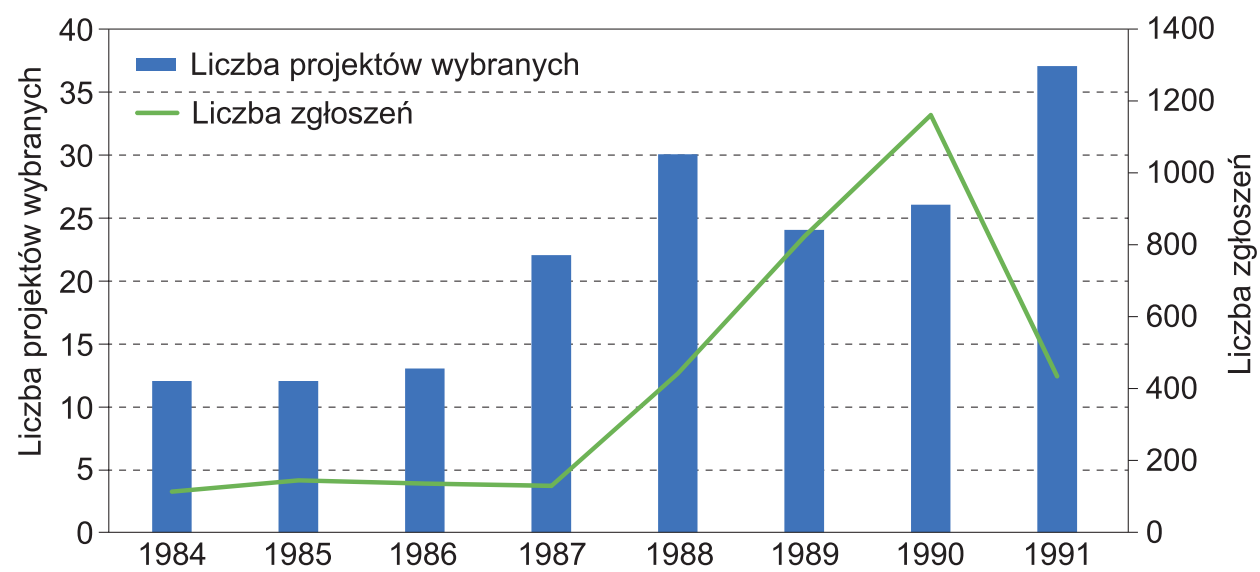

Wykres 2. Liczba zgoszeń i projektów wybranych

Źródło: opracowanie własne na podstawie: Communication from the Commission to the Council, the European Parliament and the Economic and Social Committee, New Prospect for Community Cultural Action, COM (92) 149 Final, Brussels 29 April 1992.

Tabela 1 pokazuje, że od 1987 r. rosła wyraźnie liczba zgłaszanych projektów konserwatorskich, co świadczyło o wzroście zainteresowania programem, a także 
rosnących potrzebach sektora. Najwięcej zgłoszeń przypadło na lata 1987-1990. W stosunku do 1984 r. liczba zgłoszeń wzrosła trzykrotnie. Wraz z rozwojem zgłoszeń zwiększała się też liczba projektów, którym przyznano dofinansowanie, z tym że najwięcej projektów subsydiowano w 1988 r. (30) oraz w 1991 r. (37). W sumie liczba wybranych projektów również zwiększyła się trzykrotnie pomiędzy rokiem 1984 a 1991. Ponieważ średnia wysokość grantu nie ulegała aż tak dużym zmianom po 1987 r., można zaryzykować twierdzenie, że panel ekspertów kładł nacisk na dofinansowanie prestiżowych i większych projektów niż na obdzielenie wszystkich wygranych po równo. Ponadto to, że udział projektów zaakceptowanych nigdy nie przekroczył $18 \%$ dotacji, a średnio wynosił tylko 8\%, oznacza, iż wysokość dotacji na zwycięskie granty również rosła - w ciągu siedmiu lat czterokrotnie.

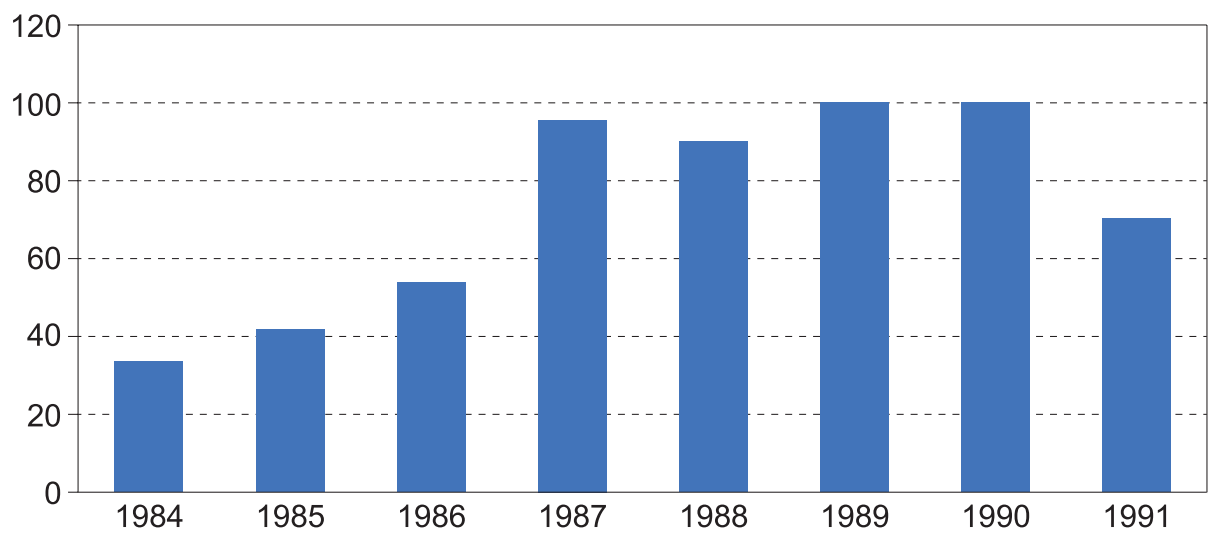

Wykres 3. Średnia wysokość grantu (w tys. ECU)

Źródło: opracowanie własne na podstawie: Communication from the Commission to the Council, the European Parliament and the Economic and Social Committee, New Prospect for Community Cultural Action, COM (92) 149 Final, Brussels 29 April 1992.

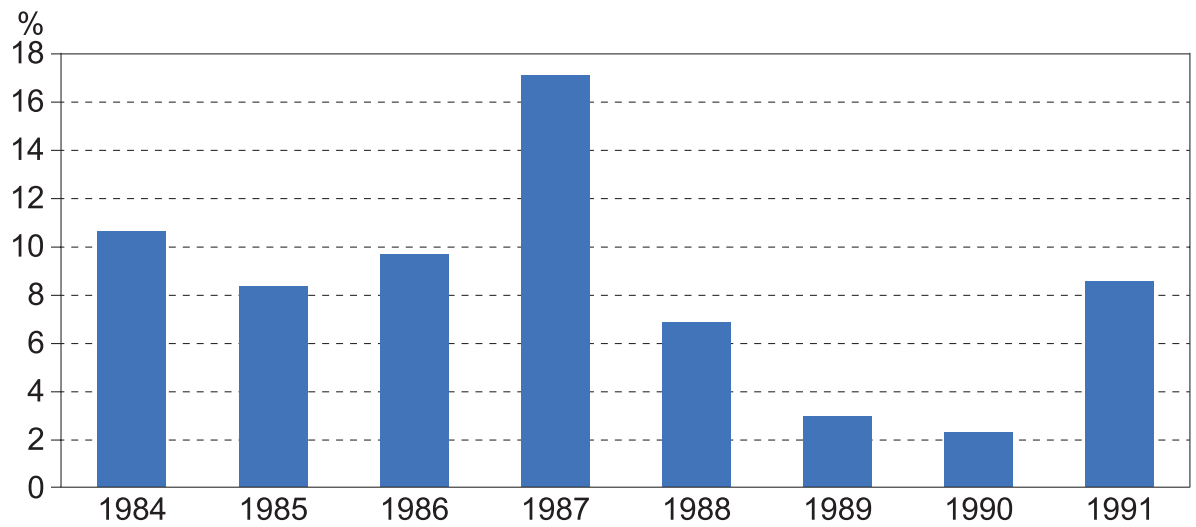

Wykres 4. Wybrane projekty

Źródło: opracowanie własne na podstawie: Communication from the Commission to the Council, the European Parliament and the Economic and Social Committee, New Prospect for Community Cultural Action, COM (92) 149 Final, Brussels 29 April 1992. 
Niestety autor raportu nie podaje źródła dofinansowania. Przy założeniu, że wsparcie dla zabytków we Wspólnocie Europejskiej odbywało się najczęściej poprzez fundusze strukturalne i programy wspólnotowe, opisany proces pomocy finansowej był pierwszą próbą udzielania dotacji celowych z bieżącego budżetu Komisji jako odpowiedź na rosnące zapotrzebowanie sektora kultury oraz znaczenie kultury w procesie integracyjnym.

Warto w tym momencie przypomnieć, że już w 1981 r. Parlament Europejski przyjął rezolucję $e^{20}$ ustanawiającą opiekę nad renowacją klasztoru góry Athos, co dowodziło determinacji greckich parlamentarzystów. Zespół klasztorny ortodoksyjnego prawosławia to jeden z najstarszych zabytków chrześcijańskich w Europie. Znajdował się na liście światowego dziedzictwa UNESCO. Według polityków nie budziło wątpliwości, że problem Athos nie jest już problemem greckim, ale - jak pisano $\mathrm{w}$ rezolucji — „problemem Wspólnoty i cywilizowanego świata, problemem nie tylko Kościoła prawosławnego, ale wszystkich chrześcijan"21. Pomoc dla kompleksu prawosławnego na Athos została uruchomiona de facto w $1987 \mathrm{r}$. w ramach obszaru drugiego (2) akcji kulturalnej zainicjowanej w 1984 r. Ta część akcji nosiła nazwę „Dofinansowanie prac konserwatorskich prowadzonych w europejskich obiektach o szczególnej wartości historycznej”. Z kolei w 1983 r. w ramach tej samej akcji ruszyło dofinansowanie do generalnego remontu greckiego Akropolu i Partenonu. Grecki rząd rozpoczął regularną odnowę tego antycznego kompleksu w 1975 r. $^{22}$ Wraz z objęciem funkcji ministerialnej przez Malinę Mercouri rozpoczęła się całościowa renowacja Akropolu, finansowana z greckiego budżetu centralnego, UNESCO oraz Wspólnoty Europejskiej. Dotacje WE były regularnie przekazywane do Aten przez lata 80 . XX w.

Zostając chwilę przy dotacjach jednorazowych, trzeba podkreślić, że rok 1988 przyniósł decyzję o kompleksowym dofinansowaniu z funduszy strukturalnych historycznego centrum Palermo oraz lizbońskiej dzielnicy Chiado. Sycylijska stolica należała w tym czasie do najbardziej niebezpiecznych miast południowych Włoch. Z powodu wysokiego wskaźnika bezrobocia cierpiała na notoryczny odpływ mieszkańców, a lokalne władze korumpowała mafia. Badania Uniwersytetu Palermo, inwentaryzujące zabytki Sycylii, szacowały, że w samym Palermo $80 \%$ budynków wymagało natychmiastowej pomocy konserwatorskiej. Plan kompleksowej renowacji historycznego centrum Palermo został przygotowany przez władze miasta w $1983 \mathrm{r}$. Poparty przez Radę Regionu Sycylia, inne miasta wyspy, a także włoski rząd znalazł swój finał w postaci rezolucji PE, ustanawiającej pomoc Wspólnoty w tym zakresie,

20 European Parliament resolution on economic aid to Mount Athos (monastery region), OJ C 144, 15 June 1981, s. 92.

21 "[...] is not just a Greek problem, but concerns the entire Community and the civilised world at large, and whereas is not an exclusively Orthodox problem, but problem for a Christians" - ibidem, s. 92.

22 M. Home, Greece begins work to save Parthenon, „The New York Times” 1.10.1983, http://www. nytimes.com/1983/10/02/us/greece-begins-work-to-save-parthenon.html (dostęp: 14 lisopada 2015). 
z dnia 18 lipca 1988 r. ${ }^{23}$ Pozwalała ona na wsparcie finansowe Palermo z Europejskiego Funduszu Rozwoju Regionalnego (ERDF - European Regional Development Fund). Pożyczki zostały zagwarantowane przez Europejski Bank Inwestycyjny oraz Bank Sycylii. Remontu wymagały najstarsze arabskie obiekty ścisłego centrum Palermo oraz obiekty użyteczności publicznej, a także budynki biurowe.

Ta sama rezolucja wprowadzała decyzję o udzieleniu wsparcia finansowego z Funduszy Strukturalnych jednej z najstarszych dzielnic Lizbony, Chiado ${ }^{24}$, która ucierpiała z powodu pożaru. Tu decydenci mieli na uwadze podniesienie atrakcyjności Lizbony jako stolicy Portugalii, uczynienie tej dzielnicy atrakcyjną turystycznie, lecz także ochronę dziedzictwa krajobrazowego oraz przyszłe możliwości komercyjnego wykorzystania kwartału. Również w tym wypadku fundusze pomocowe tworzono w sposób krzyżowy: urząd miasta Lizbona, regiony skupione wokół Lizbony oraz WE i Europejski Bank Inwestycyjny. Portugalia otrzymała ponadto pomoc z funduszy strukturalnych na odnowę części Uniwersytetu Coimbra, w której zlokalizowano studia europejskie. Podobne łączenie funduszy zostało wykorzystane w przypadku renowacji części historycznych Belfastu i Neapolu.

Tabela 2 przedstawia dane liczbowe ilustrujące pomoc Wspólnoty Europejskiej dla wybranych obiektów w latach 1983-1991 (w tys. ECU). Dofinansowanie prac restauracyjnych i konserwatorskich zostało przekazane przez KE w ramach drugiego obszaru akcji kulturalnej inicjowanej w latach 80 . XX w. Akcja nosiła nazwę: „Dofinansowanie prac konserwatorskich prowadzonych w europejskich obiektach o szczególnej wartości historycznej”.

Tabela 2. Pomoc Wspólnoty Europejskiej dla wybranych obiektów w latach 1983-1991 (w tys. ECU)

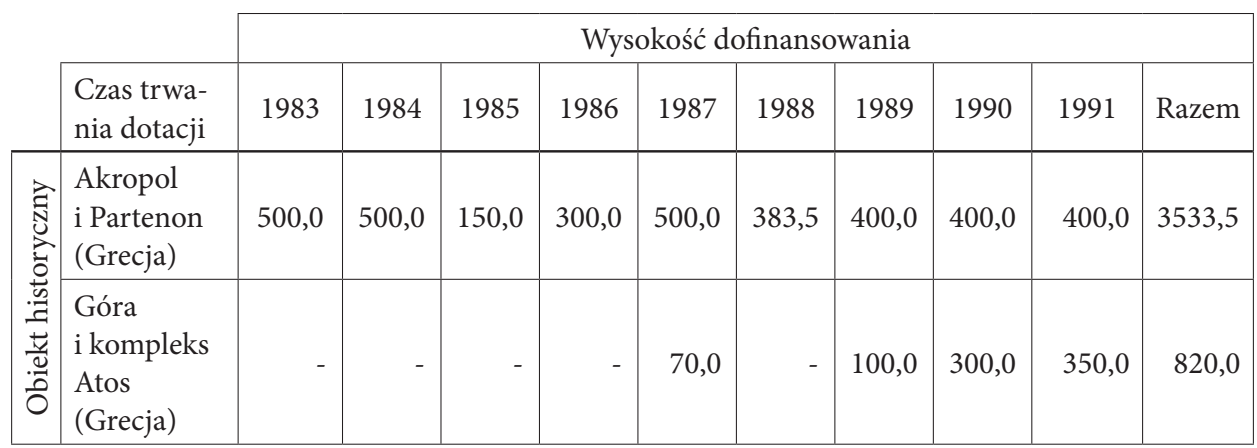

23 Resolution on the participation of community financial instruments in the restoration of the historic centre of the city of Palermo, OJ C 187, 18 July 1988, s.160.

24 Resolution on the conservation of the architectural heritage of Lisbon, OJ C 187, 18 July 1988, s. $163-164$. 


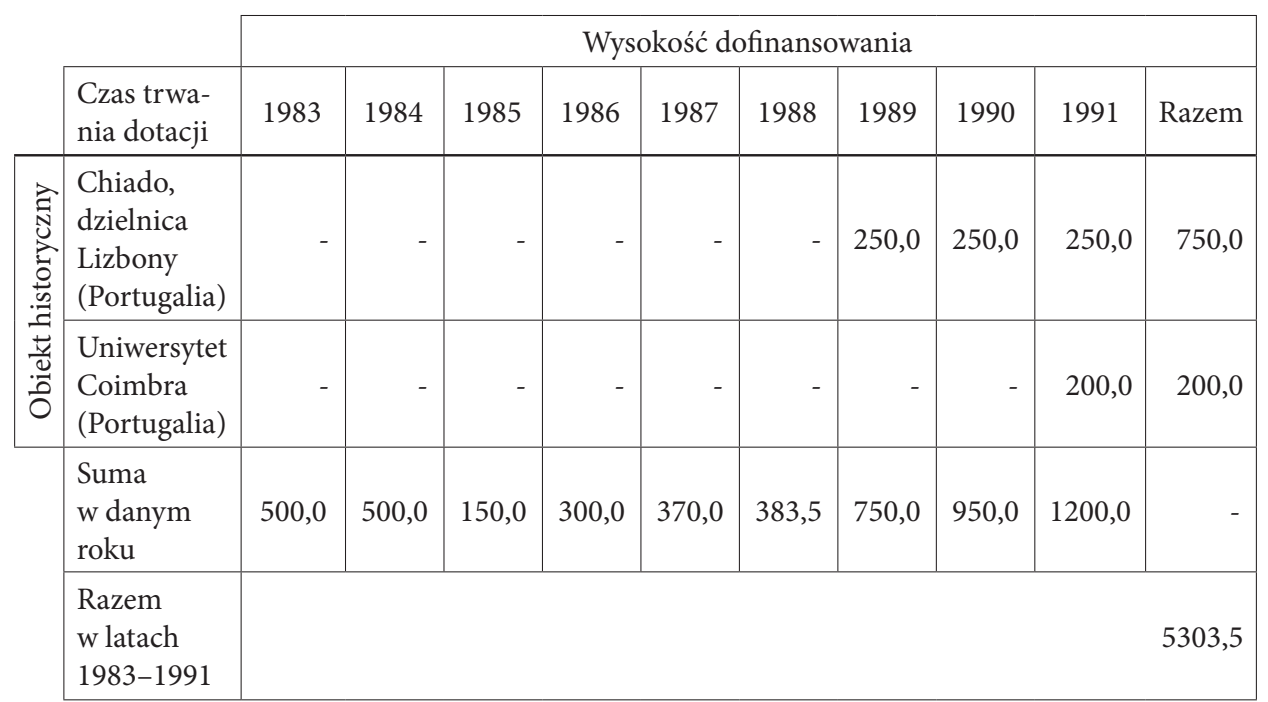

Źródło: opracowanie własne na podstawie: Communication from the Commission to the Council, the European Parliament and the Economic and Social Committee, New Prospect for Community Cultural Action, COM (92) 149 Final, Brussels 29 April 1992.

Analizując przedstawione dane, widzimy wyraźnie, że pomoc dla wybranych miejsc europejskiego dziedzictwa historycznego nieznacznie rosła w latach 19831991. Miejscami szczególnie chronionymi przez państwa Wspólnoty stały się zabytki greckie i portugalskie, gdyż wymagały one natychmiastowej pomocy. Najwięcej funduszy zostało przekazanych do Grecji ma renowację zabytków, co do których nie było wątpliwości, że stanowią symbol narodzin demokracji europejskiej i religii chrześcijańskiej. Greckie obiekty otrzymały razem w latach 80. ponad 4000 ECU, a portugalskie ok. 1000 ECU. Razem w latach 80. Wspólnota Europejska przeznaczyła z funduszy strukturalnych kwotę ponad $5000 \mathrm{ECU}^{25}$.

Program wsparcia Komisji Europejskiej dla dziedzictwa, zapoczątkowany w 1984 r., trwał w postaci tematycznych programów pilotażowych ustanowionych na lata 1989-1995 ${ }^{26}$. Natomiast w ramach trzeciego (3) zakresu Akcji Komisji,

25 Należy dodać, że po przyjęciu traktatu z Maastricht i zgodnie z rezolucją odnoszącą się do pożaru katalońskiej opery w Barcelonie w 1994 r. Unia Europejska wyasygnowała kwotę na odbudowę tego obiektu. Kwota ta została zabezpieczona w budżecie programu ochrony dziedzictwa europejskiego na rok 1994. Zob. Resolution on the fire at the Gran Theatro del Liceo, Barcelona, OJ N 61, 28 February 1994, s. 184.

26 Ustalono, że aby zmienić naturę działań z inicjatyw ad hoc, przyjmowanych pojedynczymi rezolucjami, należy ustalić programy pilotażowe, które obejmowałby większe spectrum aktywności i szersze obszary. I tak w 1990 r. dofinansowanie zostało skierowane na odnowę „Religijnych i świeckich zabytków o wyjątkowym znaczeniu”, następnie w 1990 r. — „Budowle i zespoły historyczne definiujące i charakteryzujące model miejski i wiejski”, w 1991 r. — „Świadectwa aktywności w dziedzinie produkcji rolnej, rzemieślniczej, przemysłowej itp.”, w 1992 r. — „Projekty prac konserwatorskich w miastach, przywrócenie zabytkom i ich bezpośredniemu otoczeniu pierwotnego wyglądu”, w 1993 r. — „Projekty dotyczące ogrodów historycznych”, w 1994 r. — „Zabytkowe budowle i miejsca 
pod nazwą „Granty na studia zaawansowane z zakresu technik konserwatorskich”, fundusze Wspólnot trafiły do sześciu ośrodków badawczych w latach 1989-1991. Środki te sumuje tabela 3.

Tabela 3. Dofinansowanie Wspólnoty Europejskiej w ramach „Grantów na studia zaawansowane z zakresu technik konserwatorskich" (w tys. ECU)

\begin{tabular}{|c|c|c|c|c|c|}
\hline & \multirow[b]{2}{*}{ Czas trwania dotacji } & \multicolumn{4}{|c|}{ Wysokość grantu } \\
\hline & & 1989 & 1990 & 1991 & Razem \\
\hline \multirow{7}{*}{ 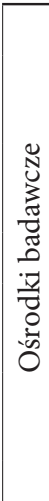 } & ICCROM, Rzym, Włochy & 38000 & 38000 & 36600 & 112600 \\
\hline & $\begin{array}{l}\text { Centre for the Conservation of Historic Towns } \\
\text { and Buildings, Leuven, Belgia }\end{array}$ & 60000 & 86000 & 88000 & 234000 \\
\hline & $\begin{array}{l}\text { Centre for Conservation Studies, York, Wielka } \\
\text { Brytania }\end{array}$ & 20000 & 35000 & 45000 & 100000 \\
\hline & Pro Venetia Viva, Wenecja, Włochy & 52500 & 52500 & 67760 & 172760 \\
\hline & $\begin{array}{l}\text { Institute of Archeology Conservation on Summer } \\
\text { School, Londyn, Wielka Brytania }\end{array}$ & 10000 & 16800 & 22280 & 49080 \\
\hline & $\begin{array}{l}\text { Centro Universitario Europeo per I Beni Culturali, } \\
\text { Ravello, Włochy }\end{array}$ & 30000 & 35000 & 43000 & 108000 \\
\hline & Razem & 210500 & 263300 & 302640 & 776440 \\
\hline
\end{tabular}

Źródło: opracowanie własne na podstawie: Communication from the Commission to the Council, the European Parliament and the Economic and Social Committee, New Prospect for Community Cultural Action, COM (92) 149 Final, Brussels 29 April 1992.

Mimo że w wypadku dofinansowania centrów edukacyjnych kształcących przyszłych specjalistów od opieki nad obiektami dziedzictwa narodowego nie mieliśmy do czynienia z dużymi kwotami, to jednak sam fakt wsparcia wskazuje na dobrą wolę Komisji, tym bardziej że niektóre z ośrodków od lat współpracowały z UNESCO i Radą Europy. Z pewnością największa dotacja została w omawianych latach przekazana ośrodkowi w Leuven, który do dziś uchodzi za prestiżowe centrum edukacji konserwatorskiej, podobnie jak fundacja Pro Venetia, działająca obecnie pod patronatem UNESCO.

Równolegle do działań Komisji pojawiały się kolejne rezolucje i rozporządzenia mające na celu usprawnienie działania państw Wspólnoty w zakresie ochrony dziedzictwa. Ważne postulaty zawierała Rezolucja ministrów kultury ${ }^{27}$ z 1986 r. Wśród nich wymieniono m.in. wymianę informacji oraz rozwijanie efektywnej współpracy z krajami trzecimi. Ministrowie wnosili też postulat standaryzacji ter-

związane ze sztukami scenicznymi, takie jak: sale koncertowe, opery, teatry" i w 1995 r. (ostatnim) — „Konserwacja zabytków architektury sakralnej”. Warto dodać, że programach pilotażowych KE wzięła udział również Polska.

27 Resolution of the Council of the Ministers responsible for Cultural Affairs meeting with the Council of 13 November 1986 on the protection of Europe's architectural heritage, OJ C 320, 13 December 1986, s. 2. 
minologii w zakresie dziedzictwa oraz promocji świadomości ekonomicznych, społecznych i kulturowych aspektów europejskiego dziedzictwa architektury. Dostrzegając inicjowany przez Radę Europy projekt Szlaków Kulturowych, 17 lutego 1986 r. Rada ministrów kultury Wspólnoty wydała rezolucję ${ }^{28}$ popierającą tworzenie ponadnarodowych traktów śladami najstarszych zabytków kultury europejskiej lub związków kulturowych (np. hanzeatyckich miast, tras pielgrzymkowych). Uznano, że tworzenie szlaków kulturowych sprzyja rozwojowi ruchu turystycznego, dynamice ekonomicznej oraz kreuje nowe miejsca pracy, ale nade wszystko stwarza możliwość uczenia się historii kontynentu.

Kolejna rezolucja, dotycząca ochrony europejskiego dziedzictwa architektonicznego $^{29}$, wskazywała dodatkowo na kwestie metodologiczne w przedmiocie konserwacji zabytków (ujednolicenie terminologii), międzynarodowy transfer nowoczesnych technologii konserwacji oraz ekonomiczny wymiar dziedzictwa, który może skutkować współpracą z biznesem.

Z kolei sektorowi komercyjnemu w kulturze i dziedzictwu została poświęcona Rezolucja z 13 listopada 1986 r. ${ }^{30}$ Ministrowie rekomendowali w niej krajom członkowskim rozwijanie mechanizmu publiczno-prywatnego partnerstwa w dziedzinie kultury oraz poszukiwanie alternatywnych źródeł finansowania:

Ministrowie twierdzą, że sponsoring biznesu nie musi przeciwdziałać wolności artystycznej. Wierzą, że powinien stanowić dodatkowe źródło finansowania aktywności kulturalnej, nie zaś stać się substytutem dotychczas już istniejących ${ }^{31}$.

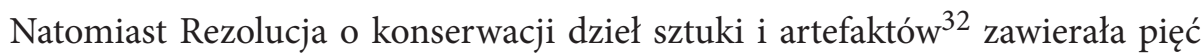
konkretnych postulatów: (1) koordynację publicznych i prywatnych działań konserwatorskich, (2) tworzenie dokumentacji odnoszącej się do zabytków o znaczeniu kulturowym i historycznym, (3) organizowanie warsztatów i treningów konserwatorskich sponsorowanych przez budżety publiczne i prywatne; (4) wymianę informacji i naukowych opracowań oraz (5) stworzenie przewodnika po konserwacji zabytków, zawierającego dane techniczne i dostępne ekspertyzy.

28 Resolution of the Ministers responsible for cultural affairs, meeting within the Council of 17 February 1986 on the establishment of transnational cultural itinerariers, OJ C 44/2, 26 February 1986 (86/C 44/02).

29 Resolution of the Ministers with responsibility for Cultural Affairs, meeting within the Council of 13 November 1986 on the protection of Europe's architectural heritage, OJ C 320/1, 13 December 1986 (86/C 320/01).

30 Resolution of the Ministers with responsibility for Cultural Affairs, meeting within the Council of 13 November 1986 on business sponsorship of cultural activities, OJ C 320/2, 13 December 1986 (86/C 320/02).

31 „Ministers believe that business sponsorship can be developed in ways which do not inhibit artistic freedom; and that it should provide supplementary funding for cultural activities, not a substitute for existing resources" - ibidem.

32 Resolution of the Ministers with responsibility for Cultural Affairs meeting within the Council of 13 November 1986 on the conservation of works and artefacts, OJ C 320/3, 13 December 1986 (86/C 320/03). 
Kluczową rolę dla późniejszego zapisu traktatu z Maastricht dotyczącego dziedzictwa odegrała Rezolucja Parlamentu Europejskiego z 1988 r. ${ }^{33}$, w której ochrona zabytków została explicite zdefiniowana jako zadanie cywilizacyjne wynikające z nowoczesnego pojmowania pojęcia tożsamości narodowej. Punkt C części definicyjnej dokumentu łączył problematykę dziedzictwa $\mathrm{z}$ ideą budowania nowej tożsamości europejskiej:

[...] architektoniczne, archeologiczne i artystyczne dziedzictwo Wspólnoty stworzyło wizję europejskich narodów, które nie będą już budować tożsamości w oparciu o bohaterskie wygrane odniesione na sąsiadach, ale w oparciu o stopniowe przekształcanie się form, w których elementy stałe i różne, nachodzące i wpływające nawzajem na siebie odsłaniają wspólne i różne elementy kultury europejskiej; także cywilizacji, która nie może być kształtowana ideami politycznymi. Nie można dopuścić, aby idee narodowej tożsamości kulturowej naszej cywilizacji były zniekształcane zarówno przez państwa członkowskie, a już w szczególności przez państwa stowarzyszone ze Wspólnotą ${ }^{34}$.

Tekst przypisuje kluczową rolę dziedzictwu europejskiemu (tu: archeologiczne$\mathrm{mu}$, architektonicznemu i artystycznemu) w budowaniu nowej koncepcji tożsamości kulturowej Europy. Tożsamość ta wyzbywała się proweniencji interwencjonistyczno-ekspansywnej i stanowiącej funkcję zwycięstw lub klęsk wojennych, konstruujących i podsycających lokalne patriotyzmy. W nowych czasach kształtowanie tożsamości opierać się będzie na wzajemnych wpływach kulturowych wynikających ze współczesnych procesów migracji oraz przepływu informacji, a także tradycji. Artefakty przeszłości spełnią funkcję integrującą, ponieważ to właśnie one są fizycznym znakiem zmian kulturowych. Cytowany fragment zawiera jeszcze jedno istotne przesłanie, a mianowicie o konieczności „wyjęcia” problematyki cywilizacyjnej spod decyzji politycznych poszczególnych państw członkowskich, w tym krajów stowarzyszonych, oraz stworzenie ponadpaństwowego, specjalistycznego nadzoru nad ochroną dziedzictwa. Rolę ciała sterującego miała odegrać właśnie Wspólnota Europejska, dlatego nie bez znaczenia pozostaje fakt, że dokument z 1988 r. jako pierwszy spośród dotychczasowych rekomendacji i rezolucji WE w swym tytule używa sformułowania ,architektoniczne i archeologiczne dziedzictwo Wspólnoty"35, a nie po prostu dziedzictwo kulturowe czy dziedzictwo europejskie.

33 European Parliament Resolution on the conservation of the Community's architectural and archaeological heritage, OJ C 309, 5 December 1988, s. 423-427; „Bulletin of the European Communities. Commission” 10, 1998, vol. 21. Communication and Culture, s. 35-37.

34 „[W] hereas the Community's archaeological, artistic and architectural heritage affords a vision of the European nations in which their identity is no longer constituted by epic feats at the expense of their neighbours, but rather by a gradual transition from one form to another in which the differences and the continuity, the overlapping and mutual influences, reveal both the identity an diversity of European culture, a civilisation which cannot be misrepresented in the service of any form of political ulterior motive and whose national cultural identity must not be allowed to be distorted either by the Member States or, indeed, by the states associated with the Community" ibidem, s. 424.

35 „[...] Community's architectural and archaeological heritage”. 
Zapisy art. 128 rozdz. IX. Kultura traktatu z Maastricht w sposób jednoznaczny przypisały tematykę ochrony dziedzictwa do zadań priorytetowych przyszłej Unii Europejskiej. Zacytujmy pkt 1 i pkt 2 tego artykułu z wersji skonsolidowanej:

1. Wspólnota przyczynia się do rozkwitu kultur Państw Członkowskich w poszanowaniu ich różnorodności narodowej i regionalnej, równocześnie podkreślając znaczenie wspólnego dziedzictwa kulturowego.

2. Działanie Wspólnoty zmierza do zachęcenia do współpracy między Państwami Członkowskimi oraz, jeśli to niezbędne, do wspierania i uzupełniania ich działań w następujących dziedzinach:

- pogłębiania wiedzy oraz upowszechniania kultury i historii narodów europejskich;

— zachowania i ochrony dziedzictwa kulturowego o znaczeniu europejskim;

— niehandlowej wymiany kulturalnej;

— twórczości artystycznej i literackiej włącznie z sektorem audiowizualnym ${ }^{36}$.

Określenie „wspólne dziedzictwo kulturowe” zostało tu użyte w definicji dość pojemnej, przy czym podkreślone zostaje zadanie „zachowania” i „ochrony” dziedzictwa przez UE jako jeden z głównych celów programowanej polityki kulturalnej. Zapis traktatowy obligował UE do podjęcia niezwłocznych działań na rzecz ochrony dziedzictwa. W dalszej kolejności oznaczało to, że wszystkie prowadzone do tej pory rozproszone i czynione ad hoc działania czy akty doraźnej pomocy merytorycznej i finansowej, organizowane przez państwa Wspólnoty albo nagłaśniane przez ich ministrów kultury i kierowane na obszar ochrony dziedzictwa kulturowego, zaczną podlegać kompleksowym i systemowym akcjom koordynowanym przez UE. Wzmacniało to spójność inicjowanych polityk oraz integralność systemów. Artykuł 128 potwierdzał suwerenność polityk kulturalnych krajów członkowskich oraz ustanawiał funkcję pomocową UE względem nich. Było to istotne w obliczu ewentualnych zaniechań w krajowych politykach konserwatorskich czy marnotrawienia dziedzictwa, które występowało zwłaszcza w krajach Europy Środkowo-Wschodniej, podpisujących $\mathrm{w}$ tym czasie umowy stowarzyszeniowe z UE. Unia zaczynała pełnić rolę wentyla bezpieczeństwa względem państwa, które przestawało się sprawdzać jako strażnik dziedzictwa ${ }^{37}$ w obliczu komercjalizacji, prywatyzacji zabytków i komodyfikacji dziedzictwa. Pojęcie „dziedzictwo kulturowe o znaczeniu europejskim" nabierało szczególnego sensu. Wskazywało na dodatkową troskę ze strony organów ponadkrajowych o dobra ponadnarodowe, również ze względu na wygaszanie „wszechogarniających narodowych narracji”38. Wyzwaniem czasu stawało się zatem dookreślenie terminologiczne pojęcia „dziedzictwo" oraz ustanowienie formalnego źródła finansowania tego obszaru. Zada-

36 Traktat o Unii Europejskiej w wersji skonsolidowanej, art. 167 (dawny art. 151 TW, a wcześniej art. 128), s. 122, http://europa.eu/pol/pdf/consolidated-treaties_pl.pdf (dostęp: 15 grudnia 2015).

37 J. Purchla, Dziedzictwo a transformacja, Kraków 2005.

38 K. Kowalski, O istocie dziedzictwa europejskiego - rozważania, Kraków 2013, s. 107. 
nia te znalazły zastosowanie w ogłoszonym kilka lat później przez KE programie wsparcia dziedzictwa kulturowego „Rafael” na lata 1997-2000 39 .

Reasumując przedstawiony tu rys historyczny, należy podkreślić, że pojęcie dziedzictwa europejskiego ewoluowało w ciągu lat 70. i 80. XX w. w wyniku procesów integracyjnych, stając się z czasem pojęciem coraz bardziej złożonym. Działo się tak ze względu nie tylko na ściślejszą integrację, lecz także intensywne procesy ekonomiczne i globalizacyjne. Od utożsamiania dziedzictwa $\mathrm{z}$ konserwacją i ochroną zabytków starożytnych, poprzez zdefiniowanie go jako dorobku archeologicznego i architektonicznego oraz edukacji w tym zakresie, urosło do pojęcia abstrakcyjnego, związanego $\mathrm{z}$ tematyką świadomości europejskiej. Krótko mówiąc, mozna stwierdzić, iż istotną rolę zaczęły odgrywać jego cechy niematerialne, takie jak pamięć, kolektywna pamięć i tożsamość. Dodany do niego przymiotnik „wspólne” czy „wspólna” sugerował wyodrębnienie elementów dziedzictwa rozpoznawalnych w dorobku wszystkich kultur europejskich i potraktowanie ich jako łącznych, niezależnie od ich partykularnych, narodowych funkcji. Dwie dekady zmagań z problematyką dziedzictwa, poprzedzające traktat $\mathrm{z}$ Maastricht, z pewnością tworzyły przedpole do ugruntowania przekonania o istnieniu cech jednoczących Europejczyków przez przeszłość i wspólne doświadczenie historyczne usymbolizowane dziedzictwem. Tak zdefiniowane dziedzictwo przewartościowało w dużym stopniu dotychczas używane pojęcia „zabytek” czy „ochrona zabytków”. Wprowadzało szersze pole znaczeniowe, które umożliwiało nowe rozumienie terminu poprzez summę materialnych i niematerialnych osiągnięć kulturowych Europejczyków, wypracowanych przez wieki i świadomie potraktowanych jako podlegające trosce osiągnięcia zbiorowe. Cechy dystynktywne poszczególnych kultur europejskich zaczynały być dostrzegane w perspektywie dobra kolektywnego. Tym samym w art. 128 traktatu ziściła się idea społeczeństwa europejskiego (People’s Europe), które o swojej przyszłości myśli w kategoriach zbiorowego pożytku oraz ochrony wspólnych wartości.

\section{Bibliografia}

\section{Literatura}

Buchowski M., Tożsamość Europejczyków: jedność i podziaty, [w:] Dylematy tożsamości europejskich pod koniec drugiego tysiąclecia, red. J. Mucha, W. Olszewski, Toruń 1997.

Colligaro O., From 'European cultural heritage' to 'cultural diversity', „Politigue Européenne” 3, 2014, nr 45.

Dobosz P., Pojęcie dziedzictwa kulturowego i jego znaczenie dla działań polskiej administracji publicznej wobec integracji europejskiej, „Ochrona Zabytków” 55, 2002, nr 2 (217).

Home M., Greece begins work to save Parthenon, „The New York Times” 1.10.1983, http://www.nytimes.com/1983/10/02/us/greece-begins-work-to-save-parthenon.html.

39 Decision No 2228/97/EC of the European Parliament and of the Council of 13 October 1997 establishing a Community action programme in the field of cultural heritage (the Raphael programme), OJ L 305/31, 8 November 1997. 
Kowalski K., O istocie dziedzictwa europejskiego - rozważania, Kraków 2013.

Peckham R.S., Introduction. The politics of heritage and public culture, [w:] Rethinking Heritage. Cultures and Politics in Europe, red. R.S. Peckham, I.B. Tauris, London-New York 2003.

Purchla J., Dziedzictwo kulturowe, [w:] Kultura i rozwój, red. J. Hausner, A. Karwińska, J. Purchla, Warszawa 2013.

Purchla J., Dziedzictwo a transformacja, Kraków 2005.

Ronchi A.M., Nypan T., European Legislation and European Heritage. A Growing Challenge for Sustainable Cultural Heritage Management and Use, Milan 2006.

Shore C., Building Europe: The Cultural Politics of European Integration, London-New York 2002.

Skaldowski B., Chabiera A., Lisiecki A., System ochrony dziedzictwa w wybranych krajach europejskich, „Kurier Konserwatorski” 2011, nr 11.

Tretter J., The 'value' of Europe: The political economy of culture in the European community, „Geopolitcs" 2011, nr 16, www.tandfonline.com/loi/fgeo20.

\section{Dokumenty i akty prawne}

Barzanti R., Draft Report on „New Prospect for Community Cultural Action”, DOC EN/PR/210/ 210674, European Parliament, Brussels 1992.

Community Action in the Cultural Sector. Commission Communication to the Council sent on 22 of November 1977, „Bulletin of the European Communities”, Supplement 6/77, COM (77) 560, 2 December 1977.

Commission Recommendation of 20 December 1974 to Member States concerning the protection of the architectural and natural heritage, OJ L 21, 28 January 1975.

Decision No 2228/97/EC of the European Parliament and of the Council of 13 October 1997 establishing a community action programme in the field of cultural heritage (the Raphael programme), OJ L 305/31, 8 November 1997.

Decyzje Parlamentu Europejskiego w związku z interpelacjami poselskimi:

- DOC 1-52/81,

- DOC 1-363/81,

- DOC 1-370/82,

- DOC 1-504/81,

- DOC 1-557/81,

- DOC 1-566/80,

- DOC 1-876/80.

European Parliament resolution on measures to protect the European cultural heritage, OJ C 62, 30 May 1974.

European Parliament resolution on the protection of the architectural and archaeological heritage, OJ C 267/25, 11 October 1982.

European Parliament resolution on economic aid to Mount Athos (monastery region), OJ C 144, 15 June 1981.

European Parliament resolution on the conservation of the Community's architectural and archaeological heritage, OJ C 309, 5 December 1988, „Bulletin of the European Communities. Commission" 10, 1998, vol. 21. Communication and Culture.

Konwencja o ochronie dziedzictwa architektonicznego Europy z 3 października 1985 r., Grenada 1985.

Konwencja UNESCO o ochronie dóbr kulturalnych w razie konfliktu zbrojnego z 14 maja 1954 r., Haga 1954, www.unesco.pl/fileadmin/user_upload/pdf/Haga.pdf.

Konwencja UNESCO w sprawie ochrony światowego dziedzictwa kulturalnego i przyrodniczego z 16 listopada 1972 r., Paryż 1954, http://www.unesco.pl/fileadmin/user_upload/pdf/Konwencja_o_ochronie_swiatowego_dziedzictwa.pdf. 
Ku zintegrowanemu podejściu do dziedzictwa kulturowego w Europie, Komunikat Komisji do Parlamentu Europejskiego, Rady, Europejskiego Komitetu Ekonomiczno-Społecznego i Komitetu Regionów, COM (2014) 477 (final), Bruksela 22 lipca 2014.

Narodowy Program Kultury „Ochrona zabytków i dziedzictwa kulturowego” na lata 2004-2013, Narodowa Strategia Rozwoju Kultury na lata 2004-2013, Ministerstwo Kultury i Dziedzictwa Narodowego, Warszawa 2004.

Pickard R., European Cultural Heritage. A Review of policies and practice, t. VII, Council of Europe, Strasbourg 2005.

Preserving Our Heritage, Improving our Enviromnemt. 20 Years of EU Research into Cultural Heritage, red. M. Chapuis, European Commission, Directorate General for Research Environment, Brussels 2009.

Resolution of the Council of the Ministers responsible for Cultural Affairs meeting with the Council of 13 November 1986 on the protection of Europe's architectural heritage, OJ C 320, 13 December 1986.

Resolution of the Ministers responsible for Cultural Affairs, meeting within the Council of 17 February 1986 on the establishment of transnational cultural itinerariers, OJ C 44/2, 26 February 1986 (86/C 44/02).

Resolution of the Ministers with responsibility for Cultural Affairs, meeting within the Council of 13 November 1986 on the protection of Europe's architectural heritage, OJ C 320/1, 13 December 1986 (86/C 320/01).

Resolution of the Ministers with responsibility for Cultural Affairs, meeting within the Council of 13 November 1986 on business sponsorship of cultural activities, OJ C 320/2, 13 December 1986 (86/C 320/02).

Resolution of the Ministers with responsibility for Cultural Affairs, meeting within the Council of 13 November 1986 on the conservation of works and artefacts, OJ C 320/3, 13 December 1986 (86/C 320/03).

Resolution on the participation of community financial instruments in the restoration of the historic centre of the city of Palermo, OJ C 187, 18 July 1988.

Resolution on the conservation of the architectural heritage of Lisbon, OJ C 187, 18 July 1988.

Resolution on the fire at the Gran Theatro del Liceo, Barcelona, OJ N 61, 28 February 1994.

Traktat o Unii Europejskiej w wersji skonsolidowanej, http://europa.eu/pol/pdf/consolidated-treaties_pl.pdf. 